Article

\title{
A Report on the In Vitro Antioxidant Properties of Vachellia karroo Leaf Extract: A Plant Widely Grazed by Goats in the Central Eastern Cape of South Africa
}

\author{
Emrobowansan M. Idamokoro ${ }^{1}$, Patrick J. Masika ${ }^{1,2}$ and Voster Muchenje ${ }^{1, *}$ \\ 1 Department of Livestock and Pasture Science, University of Fort Hare, Private Bag X1314, Alice 5700, \\ South Africa; mondayidamokoro@gmail.com (E.M.I.); patrick.masika@gmail.com (P.J.M.) \\ 2 Fort Cox College of Agriculture and Forestry, P.O. Box 2187, King William's Town 5600, South Africa \\ * Correspondence: vmuchenje@ufh.ac.za; Tel.: +27-4-0602-2059; Fax: +27-8-6628-2967
}

Academic Editor: Marc A. Rosen

Received: 21 December 2016; Accepted: 19 January 2017; Published: 15 February 2017

\begin{abstract}
The polyphenolic constituents and antioxidant activity of aqueous and acetone extracts of Vachellia karroo leaves were determined in order to evaluate its efficacy in scavenging radicals such as $\mathrm{DPPH}$, ferric reducing power and nitric oxide as an antioxidant model. The flavonols and flavonoid and phenolic content of the leaf extracts were also accessed using benchmark phytochemical reaction methods. Results of the phytochemical analyses revealed the presence of flavonoids and flavonol and phenolic compounds in the leaf extracts. The total phenolic content values in the aqueous and acetone leaf extracts were 7.40 and $11.09 \mathrm{mg}$ tannic acid equivalent/g of extract powder, respectively. The total flavonol and flavonoid content values of the aqueous leaf extracts were 9.90 and $53.23 \mathrm{mg}$ quercetin equivalent/g of extract, respectively, while those of the acetone leaf extracts were 1.18 and $5.18 \mathrm{mg}$ quercetin equivalent/g of extract, respectively. At $0.2 \mathrm{mg} / \mathrm{mL}$, the values for the scavenging activities of the acetone and aqueous extracts of the $V$. karroo leaves were significantly higher $(p<0.05)$ than that of the ascorbic acid but comparable to BHT against ferric oxide radicals. The findings from the study reveal that the antioxidative potentials of $V$. karroo leaf extract and could serve as free radical inhibitors, possibly acting as principal antioxidants.
\end{abstract}

Keywords: browse plant; polyphenolics; antioxidants; free radicals

\section{Introduction}

The adverse effects of oxidative stress in the animal body have become a serious concern globally. The activities of free radicals in the animal cell have been identified as inducing induce oxidative stress in the body [1]. It is known that, during stress, the animal body often generates more free radicals, such as superoxide anion radicals $\left(\mathrm{O}_{2}^{-}\right)$, nitric oxide $\left(\mathrm{NO}^{-}\right)$, reactive oxygen species (ROS), and hydroxyl radicals $(\mathrm{OH})$, than both enzymatic antioxidants (e.g., glutathione (GPx) and catalase) and synthetic antioxidants (e.g., carotenoids, flavonoids, and ascorbic acid). These free radicals which are mostly generated during biological and physiological processes are recognized as causing cell damage and, in severe cases, may result in cell death [2]. Consequently, oxidative stress in animals has been identified as being involved with several disease processes such as enteritis, pneumonia, mastitis, sepsis, and joint disease [3].

The search for natural antioxidants as therapeutic agents to suppress the role of free radicals in the pathogenesis of some diseases that affect animals is now gaining global attention. Quite a number of synthetic antioxidant agents including butylated hydroxytoluene (BHT) and butylated hydroxyanisole (BHA) have been used to suppress the upshot of free radicals in animal cells [4]. However, these synthetic agents (BHT and BHA) have been reported to have toxic effects on animals [5]. 
Conversely, research has shown that several medicinal plants possess chemical substances that display antioxidant potentials [6]. Natural antioxidants from the intake of plant parts have been reported to reduce the adverse effect of free radicals that normally occur during cell metabolism [7]. Plant phenolics are principally the source of natural antioxidants and are originally derived from plant parts including seeds, nuts, roots, barks, and leaves [8].

Vachellia karroo (sweet thorn), belonging to the legume family Fabaceae, is an abundantly spread browse plant in the dry region of South Africa. The leaves of V. karroo are widely consumed by goats [9]. They are rich in crude protein and certain essential amino acids [10]. Vachellia karroo leaves have been used to reduce worm loads in cattle [11] and to improve the immune systems and meat quality of goats [12]. Studies have also shown that the leaves of $V$. karroo can be utilized to improve the growth rate of goats [13] and steers [14]. The utility potential of $V$. karroo leaves portend its worth as a resourceful plant material for improving animal welfare and production [12,13]. The aim of the current study was to report the phytochemical contents and antioxidant activities of both the aqueous and acetone extracts of $V$. karroo leaves in vitro. The results from this study will possibly add to the merit of the therapeutic potential of $V$. karroo leaves, as there are very sparse studies (if any) to our knowledge that have investigated the phytochemical constituent and antioxidant activities for this plant ecotype in the area of current study.

\section{Materials and Methods}

\subsection{Collection of Plant}

The leaves of V. karroo were collected from the Central Eastern Cape Province of South Africa in August 2015. The region ordinarily falls within $30^{\circ} 00^{\prime}-34^{\circ} 15^{\prime} \mathrm{S}$ (Latitude) and $22^{\circ} 45^{\prime}-30^{\circ} 15^{\prime} \mathrm{E}$ (Longitude). The common name for the plant by the Xhosa speaking people in the study area is Umunga. The plant was identified and validated by Professor Don Grierson at the Giffen Herbarium of the Botany Department, University of Fort Hare, and voucher specimens (Aded Med 2007/1-10) were deposited in the herbarium.

\subsection{Preparation of Extract}

Leaves were air dried at room temperature to constant weights. After drying, the plant materials were ground to a fine powder. Sixty grams each of the ground plant materials were extracted in water and acetone solvent (1:10 $v / v)$ separately for $48 \mathrm{~h}$ in an orbital shaker (Orbital Incubator Shaker, Gallenkamp) at $140 \mathrm{rev} / \mathrm{min}$. Extracts of the plant sample were filtered using a Buckner funnel and filter paper (Whatman No. 1). A rotary evaporator (Strike 202 Steroglass, San Martino ln Campo, Perugia, Italy) was used to concentrate the acetone extracts to dryness under reduced pressure at $57^{\circ} \mathrm{C}$. The filtrate from the water extract was frozen for $48 \mathrm{~h}$ at a temperature of $-40{ }^{\circ} \mathrm{C}$ using a freeze dryer (Vir Tis benchtop K, Vir Tis Co., Gardiner, NY, USA). Each leaf extracts (i.e., water and acetone) were re-suspended in the respective solvents to make a $50 \mathrm{mg} / \mathrm{mL}$ stock solution.

\subsection{Reagents and Chemicals Used}

The given chemicals that were used during the study were as follows: ascorbic acid, butylated hydroxytoluene (BHT), 1,1-diphenyl-2-picrylhydrazyl (DPPH), Folin-Ciocalteu's reagent $\left(3 \mathrm{H}_{2} \mathrm{O} \cdot \mathrm{P}_{2} \mathrm{O}_{5} \cdot 13 \mathrm{WO}_{3} \cdot 5 \mathrm{MoO}_{3} \cdot 10 \mathrm{H}_{2} \mathrm{O}\right)$, sodium carbonate $\left(\mathrm{Na}_{2} \mathrm{CO}_{3}\right)$, sodium nitroprusside $\left(\mathrm{Na}_{2}\left[\mathrm{Fe}(\mathrm{CN})_{5} \mathrm{NO}\right]\right)$, tannic acid, ferric chloride $\left(\mathrm{FeCl}_{3}\right)$, trichloroacetic acid (TCA) phosphate buffer, and potassium ferricyanide $\left[\mathrm{K}_{3} \mathrm{Fe}(\mathrm{CN})_{6}\right]$. Chemicals were obtained from Merck Chemical Supplies (Wadeville, South Africa). All chemicals and solvents used were of analytical standard.

\subsection{Determination of Total Phenols}

The modified Folin-Ciocalteu method was employed to determine the total phenolic content of the extract [15]. Briefly, $5 \mathrm{~mL}$ of Folin-Ciocalteu reagent was diluted with distilled water $(1: 10 v / v)$ and 
$4 \mathrm{~mL}(75 \mathrm{~g} / \mathrm{L})$ of sodium carbonate before mixing with the $0.5 \mathrm{~mL}$ aliquot of leaf extract $(1 \mathrm{mg} / \mathrm{mL})$. The tubes (containing the mixtures) were vortexed thoroughly for $15 \mathrm{~s}$. The mixture was allowed to settle for $30 \mathrm{~min}$ at $40{ }^{\circ} \mathrm{C}$ for colour development. The absorbance was measured at $765 \mathrm{~nm}$ using the AJI-C03 UV-VIS (Eastern Cape lab services, Eastern Cape, South Africa) spectrophotometer by putting $4 \mathrm{~mL}$ of the prepared mixture into a cuvette before placing it inside the spectrophotometer to take readings (absorbance). The total phenolic content was expressed as mg tannic acid/g dry material based on the given equation on the calibration curve: $Y=0.1216 X, R^{2}=0.9365$. From the equation, $\mathrm{Y}$ represents the absorbance and $\mathrm{X}$ represents tannic acid equivalent.

\subsection{Determination of Total Flavonoids}

The total flavonoid content values of the plant extracts were determined by the method employed by [16]. Briefly, a volume of $0.5 \mathrm{~mL}$ of $2 \% \mathrm{AlCl}_{3}$ was prepared in acetone and added to $0.5 \mathrm{~mL}$ of the extracts. The mixture was left to stand for $60 \mathrm{~min}$ at room temperature, and the absorbance measured at $420 \mathrm{~nm}$. A colour change (yellow) indicated the presence of flavonoids. The extract samples were evaluated at a final concentration of $0.1 \mathrm{mg} / \mathrm{mL}$. The results of the total flavonoid content were evaluated as quercetin $(\mathrm{mg} / \mathrm{g})$ using the given equation $\left(Y=0.0255 \mathrm{X}, \mathrm{R}^{2}=0.9812\right)$ based on the calibration curve, where $Y$ represents the absorbance and $X$ represents quercetin equivalent $(\mathrm{mg} / \mathrm{g})$.

\subsection{Determination of Total Flavonols}

Total flavonols of the V. karroo extracts were estimated based on the method used in [17]. Plant extracts of $0.4 \mathrm{~mL}$ each were mixed with $0.4 \mathrm{~mL}$ of $\mathrm{AlCl}_{3}$ (already prepared in acetone). This was followed by adding $0.6 \mathrm{~mL}$ of a sodium acetate solution $(50 \mathrm{~g} / \mathrm{L})$. The absorbance was read at $440 \mathrm{~nm}$ after incubation for $170 \mathrm{~min}$ at $20^{\circ} \mathrm{C}$. Total flavonols were estimated using the given equation $\left(Y=0.0255 X, R^{2}=0.9812\right)$ based on the calibration curve, where $Y$ represents the absorbance, and $X$ represents quercetin equivalent $(\mathrm{mg} / \mathrm{g})$.

\section{Antioxidant Assay}

\subsection{DPPH Radical Scavenging Activity}

The activity of the acetone and water extract on DPPH radical was evaluated using the method in [18]. In brief, $0.135 \mathrm{mM}$ of DPPH in acetone was prepared and $1.0 \mathrm{~mL}$ of the solution was then mixed with $1.0 \mathrm{~mL}$ of extract in acetone and water containing $0.2-1.0 \mathrm{mg} / \mathrm{mL}$ of the leaf extract, respectively. The mixtures were left in the dark for $30 \mathrm{~min}$ at room temperature to ascertain the extract reaction on the DPPH radical. Absorbance of the mixture was read spectrophotometrically at $517 \mathrm{~nm}$, with BHT and ascorbic acid used as references. The ability of the extract to scavenge DPPH radical was determined using the given equation: \% inhibition $=\left[\left(\mathrm{Abs}_{\text {control }}\right)-\left(\mathrm{Abs}_{\text {sample }}\right)\right] /\left[\left(\mathrm{Abs}_{\text {control }}\right)\right] \times 100$. From the given equation, $\mathrm{Abs}_{\text {control }}$ represents the absorbance of DPPH radical + ethanol; $\mathrm{Abs}_{\text {sample }}$ represents the absorbance of DPPH radical + sample extract/standard.

\subsection{Ferric Reducing Anti-Oxidant Property (FRAP Assay)}

The ferric reducing anti-oxidant property was determined using the method of [19]. Briefly, a mixture of $2.5 \mathrm{~mL}$ of $0.2 \mathrm{M}$ phosphate buffer $(\mathrm{pH} 6.6)$ and $2.5 \mathrm{~mL}$ of $1 \% w / v$ of $\mathrm{K}_{3} \mathrm{Fe}(\mathrm{CN})_{6}$ was added to the extracts $(1.0 \mathrm{~mL})$ and standards $(0.2-1.0 \mathrm{mg} / \mathrm{mL})$ prepared in water and acetone. The mixture was then incubated $(20 \mathrm{~min})$ at a temperature of $50{ }^{\circ} \mathrm{C}$, after which $2.5 \mathrm{~mL}$ of TCA $(10 \% w / v)$ was added to the mixture and was centrifuged (at $3000 \mathrm{rpm})$ for $10 \mathrm{~min}$. The supernatant $(2.5 \mathrm{~mL})$ obtained from the centrifuge of the mixture was mixed with $0.5 \mathrm{~mL}$ of $\mathrm{FeCl}_{3}(0.1 \% \mathrm{w} / \mathrm{v})$ and $2.5 \mathrm{~mL}$ of distilled water. Absorbance was then measured spectrophotometrically at $700 \mathrm{~nm}$ against a blank sample. A high reducing power of the reaction mixture of the plant extracts was indicated by an increased absorbance. 


\subsection{Nitric Oxide Radical Scavenging Activity}

The modified method as described by [20] was used to determine the nitric oxide radical scavenging activity of the extracts (aqueous and acetone) of $V$. karroo leaves. Briefly, $2 \mathrm{~mL}$ of $10 \mathrm{mM}$ sodium nitroprusside in $0.5 \mathrm{~mL}$ of phosphate buffer saline ( $\mathrm{pH} 7.4$ ) was added to $0.5 \mathrm{~mL}$ of the plant extracts, ascorbic acid, and BHT at different concentrations $(0.2-1.0 \mathrm{mg} / \mathrm{mL})$. The mixture was then incubated for $150 \mathrm{~min}$ at a temperature of $25^{\circ} \mathrm{C}$. After incubation, $0.5 \mathrm{~mL}$ of the mixture was mixed with $0.5 \mathrm{~mL}$ of sulfanilic acid reagent and thereafter incubated for $5 \mathrm{~min}$ at room temperature. One milliliter of naphthylethylenediamine dihydrochloride $(0.1 \% w / v)$ was finally added to the mixture and again incubated at room temperature for another $30 \mathrm{~min}$, after which the absorbance was measured at $540 \mathrm{~nm}$ with a spectrophotometer. The ability of the extract to scavenge nitric oxide radicals was calculated using the given equation: \% inhibition $=\left[\left(\mathrm{Abs}_{\text {control }}\right)-\left(\mathrm{Abs}_{\text {sample }}\right)\right] /\left[\left(\mathrm{Abs}_{\text {control }}\right)\right] \times 100$. From the equation, $\mathrm{Abs}_{\text {control }}$ represents the absorbance of nitric oxide radical + acetone; $\mathrm{Abs}_{\text {sample }}$ represents the absorbance of nitric oxide radical + sample extract/standard.

\section{Statistical Analysis}

The experimental findings were expressed as mean \pm standard deviation (STD) in triplicate. The values were analysed using PROC GLM procedures of SAS (version 9.1.3 of 2007, SAS Institute Inc., Cary, NC, USA) [21]. Tukey's Studentised Range procedure was used to test for any significant difference between the solvents and the standard drugs, which was then used to determine the antioxidant properties of the extracts. Statistical significance was considered at $p<0.05$.

\section{Results}

\subsection{Polyphenolic Constituents}

Result of the phytochemical analysis of the V. karroo leaf extracts revealed the presence of phenols, flavonols, and flavonoids (Table 1). The concentrations of phenolic compounds in the aqueous and acetone solvent extract were considerably high for total phenols and total flavonols and low for total flavonoids. The phenol, flavonol and flavonoid content from the leaf extracts was higher in the acetone solvent compared to the aqueous solvent (Table 1).

Table 1. Polyphenolic content of aqueous and acetone extracts of $V$. karroo leaves.

\begin{tabular}{ccc}
\hline Phenolics & Aqueous & Acetone \\
\hline Total phenols $^{\mathrm{x}}$ & $7.40 \pm 0.01$ & $11.09 \pm 0.01$ \\
Total flavonols $^{\mathrm{y}}$ & $9.88 \pm 0.04$ & $53.23 \pm 0.00$ \\
Total flavonoids $^{\mathrm{z}}$ & $1.18 \pm 0.02$ & $5.18 \pm 0.00$ \\
\hline
\end{tabular}

STD = standard deviation. Values are means of triplicate determinations \pm STD. ${ }^{x}$ Expressed as mg tannic acid $/ \mathrm{g}$ of dry plant material; ${ }^{y}$ Expressed as mg quercetin/g of dry plant material; ${ }^{z}$ Expressed as mg quercetin/g dry plant material.

\subsection{DPPH Radical Scavenging Activity}

The dose-response curve of the DPPH radical scavenging activity of the aqueous extracts of V. karroo leaf compared favourably with those for ascorbic acid and BHT (Table 2). From the result, it was observed that the aqueous extract of $V$. karroo leaf had higher activity than the acetone extract. At a concentration of $0.2 \mathrm{mg} / \mathrm{mL}$, the scavenging activity of aqueous and acetone extracts reached $79.12 \%$ and $76.34 \%$, while the standard drugs used (i.e., ascorbic acid and BHT) were $85.46 \%$ and $87.28 \%$. The $\mathrm{IC}_{50}$ value for aqueous and acetone leaf extracts, ascorbic acid, and BHT are presented in Table 5 . 
Table 2. DPPH radical scavenging activity of aqueous and acetone extracts of $V$. karroo leaves compared to known standards.

\begin{tabular}{|c|c|c|c|c|c|c|c|c|c|}
\hline \multirow{2}{*}{$\begin{array}{c}\text { Conc. } \\
\mathrm{mg} / \mathrm{mL}\end{array}$} & \multicolumn{2}{|c|}{ Aqueous } & \multicolumn{2}{|c|}{ Acetone } & \multicolumn{2}{|c|}{ Ascorbic Acid } & \multicolumn{2}{|l|}{ BHT } & \multirow{2}{*}{$p$-Value } \\
\hline & $\%$ Inhibition & STD & $\%$ Inhibition & STD & $\%$ Inhibition & STD & $\%$ Inhibition & STD & \\
\hline 0.2 & $79.12^{b}$ & 1.03 & $76.34^{b}$ & 0.66 & $85.46^{a}$ & 2.86 & $87.28^{a}$ & 0.21 & 0.0001 \\
\hline 0.4 & $76.02^{b}$ & 2.47 & $70.78^{b}$ & 2.68 & $86.07^{\mathrm{a}}$ & 0.82 & $84.24^{\mathrm{a}}$ & 3.39 & 0.0002 \\
\hline 0.6 & $75.32^{c}$ & 1.29 & $61.43^{\mathrm{b}}$ & 1.40 & $87.84^{\mathrm{a}}$ & 2.12 & $87.10^{a}$ & 0.14 & 0.0001 \\
\hline 0.8 & $71.01^{b}$ & 2.41 & $58.02^{\mathrm{c}}$ & 0.77 & $87.89^{a}$ & 0.77 & $86.02^{a}$ & 2.47 & 0.0001 \\
\hline 1.0 & $75.97^{\mathrm{a}}$ & 1.97 & $47.31^{\mathrm{b}}$ & 0.71 & $83.87^{\mathrm{a}}$ & 4.74 & $83.82^{\mathrm{a}}$ & 4.70 & 0.0001 \\
\hline
\end{tabular}

Conc. = concentration; $\mathrm{BHT}=$ butylated hydroxytoluene; $\mathrm{STD}=$ standard deviation. Values are means of triplicate

determinations \pm STD. ${ }^{a, b, c}$ means with different superscripts within a row are significantly different at $p<0.05$.

\subsection{Ferric Reducing Activity Power (FRAP)}

The ferric reducing ability of the aqueous and acetone leaf extracts of $V$. karroo was within the range of $53 \%-83 \%$ (Table 3). At $0.2 \mathrm{mg} / \mathrm{mL}$, the values for the acetone and aqueous extracts of the $V$. karroo leaves were significantly higher than that of the ascorbic acid but comparable to BHT. The $\mathrm{IC}_{50}$ value for aqueous and acetone leaf extracts, ascorbic acid, and BHT are presented.

Table 3. Ferric reducing properties of aqueous and acetone extracts of V. karroo leaves compared to known standards.

\begin{tabular}{|c|c|c|c|c|c|c|c|c|c|}
\hline \multirow{2}{*}{$\begin{array}{c}\text { Conc. } \\
\mathrm{mg} / \mathrm{mL}\end{array}$} & \multicolumn{2}{|c|}{ Aqueous } & \multicolumn{2}{|c|}{ Acetone } & \multicolumn{2}{|c|}{ Ascorbic Acid } & \multicolumn{2}{|l|}{ BHT } & \multirow{2}{*}{$p$-Value } \\
\hline & $\%$ Inhibition & STD & $\%$ Inhibition & STD & $\%$ Inhibition & STD & $\%$ Inhibition & STD & \\
\hline 0.2 & $81.81^{\mathrm{a}, \mathrm{b}}$ & 5.29 & $83.80^{a, b}$ & 1.56 & $56.97^{b}$ & 23.23 & $94.46^{\mathrm{a}}$ & 1.45 & 0.0267 \\
\hline 0.4 & $76.75^{\mathrm{b}}$ & 5.95 & $73.37^{b}$ & 1.17 & $21.68^{c}$ & 3.87 & $94.34^{\mathrm{a}}$ & 1.20 & 0.0001 \\
\hline 0.6 & $69.60^{b}$ & 2.37 & $67.54^{\mathrm{b}}$ & 1.11 & $12.75^{c}$ & 3.21 & $93.97^{\mathrm{a}}$ & 0.21 & 0.0001 \\
\hline 0.8 & $56.66^{b}$ & 6.40 & $61.57^{b}$ & 0.81 & $11.67^{c}$ & 2.85 & $93.99^{a}$ & 0.07 & 0.0001 \\
\hline 1.0 & $53.81^{b}$ & 3.51 & $54.79^{\mathrm{b}}$ & 0.80 & $8.25^{c}$ & 2.40 & $92.89^{\mathrm{a}}$ & 2.36 & 0.0001 \\
\hline
\end{tabular}

Conc. = concentration; $\mathrm{BHT}=$ butylated hydroxytoluene; $\mathrm{STD}=$ standard deviation. Values are means of triplicate determinations \pm STD. ${ }^{a, b, c}$ means with different superscripts within a row are significantly different at $p<0.05$.

\subsection{Nitric Oxide Radical Scavenging Activity}

The aqueous and acetone leaf extracts of $V$. karroo were effective scavengers of the nitric oxide radicals (Table 4). The activity of the plant extracts (aqueous and acetone) was comparable to that of BHT and was more effective than that for ascorbic acid (Table 4). At $0.2 \mathrm{mg} / \mathrm{mL}$, the inhibition values (\%) were $74.08 \%, 59.81 \%, 61.19 \%$ and $50.12 \%$ for aqueous, acetone extracts, BHT and ascorbic acid, respectively. On the other hand, at $0.4 \mathrm{mg} / \mathrm{mL}$ the inhibition values (\%) were $74.69 \%, 49.53 \%, 51.71 \%$ and $37.11 \%$ for aqueous, acetone extracts, BHT and ascorbic acid, respectively. The $\mathrm{IC}_{50}$ values for aqueous and acetone leaf extracts, ascorbic acid, and BHT are presented in Table 5.

Table 4. Nitric oxide radical activities of aqueous and acetone extracts of $V$. karroo leaves compared to known standards.

\begin{tabular}{|c|c|c|c|c|c|c|c|c|c|}
\hline \multirow{2}{*}{$\begin{array}{c}\text { Conc. } \\
\mathrm{mg} / \mathrm{mL}\end{array}$} & \multicolumn{2}{|c|}{ Aqueous } & \multicolumn{2}{|c|}{ Acetone } & \multicolumn{2}{|c|}{ Ascorbic Acid } & \multicolumn{2}{|l|}{ BHT } & \multirow{2}{*}{$p$-Value } \\
\hline & \% Inhibition & STD & $\%$ Inhibition & STD & \% Inhibition & STD & $\%$ Inhibition & STD & \\
\hline 0.2 & $74.08^{a}$ & 1.01 & $59.81^{b}$ & 1.04 & $50.12^{c}$ & 6.53 & $61.19^{b}$ & 2.24 & 0.0003 \\
\hline 0.4 & $74.69^{a}$ & 0.76 & $49.53^{\mathrm{b}}$ & 0.88 & $37.11^{\mathrm{c}}$ & 2.78 & $51.72^{b}$ & 3.22 & 0.0001 \\
\hline 0.6 & $52.34^{\mathrm{a}}$ & 0.72 & $42.98^{a}$ & 1.05 & $20.95^{b}$ & 15.54 & $45.86^{\mathrm{a}}$ & 0.54 & 0.0058 \\
\hline 0.8 & $47.39^{a}$ & 0.38 & $46.53^{\mathrm{a}}$ & 1.90 & $10.69^{c}$ & 8.22 & $32.92^{b}$ & 0.19 & 0.0001 \\
\hline 1.0 & $40.98^{a}$ & 1.59 & $43.91^{\mathrm{a}}$ & 0.41 & $3.18^{\mathrm{b}}$ & 14.12 & $30.29^{a}$ & 0.45 & 0.0004 \\
\hline
\end{tabular}

Conc. $=$ concentration; $\mathrm{BHT}=$ butylated hydroxytoluene; $\mathrm{STD}=$ standard deviation. Values are means of triplicate determinations \pm STD. ${ }^{\mathrm{a}, \mathrm{b}, \mathrm{c}}$ means with different superscripts within a row are significantly different at $p<0.05$. 
Table 5. Inhibitory concentrations at 50\% (IC50) of the antioxidant activities of V. karroo leaf extracts compared to known standards.

\begin{tabular}{ccccccc}
\hline \multirow{2}{*}{ Sample } & \multicolumn{2}{c}{ DPPH } & \multicolumn{2}{c}{ Ferric Reducing Power } & \multicolumn{2}{c}{ Nitric Oxide } \\
\cline { 2 - 7 } & $\mathbf{I C}_{\mathbf{5 0}}$ & $\mathbf{R}^{\mathbf{2}}$ & $\mathbf{I C}_{\mathbf{5 0}}$ & $\mathbf{R}^{\mathbf{2}}$ & $\mathbf{I C}_{\mathbf{5 0}}$ & $\mathbf{R}^{\mathbf{2}}$ \\
\hline Aqueous & 0.67 & 0.98 & 0.59 & 0.96 & 0.60 & 0.90 \\
Acetone & 0.62 & 0.98 & 0.56 & 0.98 & 0.43 & 0.66 \\
Ascorbic & 0.04 & 0.01 & 0.40 & 0.72 & 0.56 & 0.98 \\
BHT & 0.66 & 0.25 & 0.74 & 0.79 & 0.56 & 0.99 \\
\hline
\end{tabular}

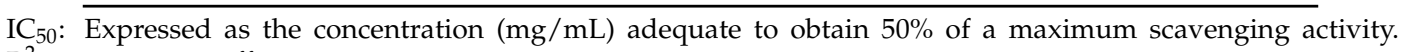
$\mathrm{R}^{2}$ : regression co-efficient.

\section{Discussion}

\subsection{Polyphenolic Constituents of V. karroo Leaf}

The main compounds present in $V$. karroo leaf extracts are polyphenols and display antioxidant activities. Polyphenols exhibit antioxidant activities due to their redox properties [22]. The redox reaction of polyphenols is vital due to their ability to adsorb and neutralize free radicals, decompose peroxides, and likewise quench the activity of reactive oxygen species [19]. The solvents used in the current study extracted an appreciable quantity of polyphenols (i.e., phenols, flavonols, and flavonoids), but the acetone solvent extracted higher phenolic compounds compared to the aqueous solvent (Table 1). A similar observation was made by the authors of [23] who reported that acetone extracted more phenolic compounds from the leaf of Carpobrotus edulis when compared to the aqueous solvent. The quantity of phenolic compounds extracted from plants is known to be solvent dependent. The reason for the variation in the extraction potential of the two solvents used in the present study could be a result of disparity in the polarity of the different solvents.

The presence of phenolic compounds identified in the leaf extracts of V. karroo in the current study could be responsible for its folkloric therapeutic usage for animals. Flavonoids, for instance, are known to be very potent water-soluble antioxidants. They help to prevent cell damage caused by oxidative stress because they exhibit strong antioxidant activities against free radicals [24]. The concentration of flavonoids extracted from the leaf of $V$. karroo was quite appreciable in both solvents that were used, but mostly in the acetone solvent. The flavonoid concentrations of the aqueous $(1.18 \mathrm{mg} / \mathrm{g})$ and acetone $(5.18 \mathrm{mg} / \mathrm{g})$ extracts from $V$. karroo in the present study were higher compared to those reported in [23] in the aqueous $(0.2 \mathrm{mg} / \mathrm{g})$ and acetone $(0.65 \mathrm{mg} / \mathrm{g})$ extracts of Carpobrotus edulis (L.) bolus leaves.

\subsection{Free Radical Scavenging Activities}

The result of the DPPH scavenging activity assay revealed that the leaf extract was potently active. The ability of the extracts to scavenge DPPH radicals was lower compared to ascorbic acid and BHT. However, the activities of the aqueous and acetone extracts $\left(\mathrm{IC}_{50}: 0.67 \mathrm{mg} / \mathrm{mL}\right.$ and $0.62 \mathrm{mg} / \mathrm{mL}$ ), respectively, were comparable to $\mathrm{BHT}\left(\mathrm{IC}_{50}: 0.66 \mathrm{mg} / \mathrm{mL}\right)$. This is an indication that the extracts possess the ability to donate protons to a free radical and thus could be used as primary antioxidants since the antioxidant effect of extracts on DPPH is speculated to be due to their ability to donate hydrogen to free radicals [25].

The ferric reducing power of the leaf extracts from the current study was evaluated by measuring the transformation of the ferricyanide complex $\left(\mathrm{Fe}^{3+}\right)$ to ferrous form $\left(\mathrm{Fe}^{2+}\right)$. From our results, the leaf extracts and the standard drugs (ascorbic acid and BHT) used were concentration-dependent; this is because the \% inhibition values of the ferricyanide complex were dependent on either the increase or decrease in the concentration of the different solvent extracts. Our findings concurred with other studies $[23,26]$ that reported that the reducing power of plant extracts from different solvents was 
concentration-dependent. The reducing ability of plant extracts to transform $\mathrm{Fe}^{2+}$ to $\mathrm{Fe}^{3+}$ could be a result of the presence of hydrophilic polyphenolic compounds such as lycopene [27].

Generally, nitric oxides are reactive free radicals produced by body cells to give more reactive species (e.g., peroxynitrite), which can be decomposed to form hydroxyl radicals. At a concentration of $0.2 \mathrm{mg} / \mathrm{mL}$, the nitric oxide scavenging activities of the aqueous extract was higher compared to the standard drugs (BHT and ascorbic acid). Consequently, the acetone extract was comparable to the BHT and higher than ascorbic acid at $0.2 \mathrm{mg} / \mathrm{mL}$ concentrations. Similar findings were also observed by the authors of [19], who reported that the aqueous extracts from Helichrysum longifolium DC leaves (plant family Asteraceae) significantly reduced the level of nitric oxide radicals.

Some browse plants produce thorns (for mechanical defence) as well as bioactive compounds (such as alkaloids, terpenes, phenolics, glucosinolates, and cyanogenic glycosides) for defence against predators; however, these compounds may turn out to be beneficial to animals and as such provide medicinal usefulness to livestock when their leaves are consumed [28]. One may wonder why goats that are raised in communal areas of South Africa graze so many V. karroo leaves when they are on the rangeland, despite the fact that the plant has thorns on their branches. The reason (aside from the plant's nutritional composition) could be because goats derive bioactive compounds from the leaves of V. karroo, which could be useful for their body metabolism. According to [14], Vachellia karroo leaves nutritionally improved blood metabolites in cattle. Furthermore, $V$. karroo leaves have been used as a supplement in livestock feed to reduce worm load [12] and to improve growth rate in goats [13]. Nonetheless, the antioxidant effects of $V$. karroo leaves on artificially or physiologically (pregnant) stressed animals should be investigated in vivo for further scientific validation of the therapeutic properties of the plant.

From personal interactions with communal farmers within the study area, it was gathered that goat farmers sometimes feed their goats with $V$. karroo leaves because it is perceived to be a valuable feed resource that improves the welfare of their animals, even though they may not have scientific evidence for this practice [29]. Masika and Mafu (2004) [30] have also reported that goats raised under a free ranging system are faced with the challenge of stress after walking long distances in search of pastures. Goats supplemented with V. karroo leaves may benefit from the antioxidant effect of polyphenolic compounds (e.g., flavonoids) present in the plant, which could protect them against free radicals that are released in the body cells during oxidative stress [24].

\section{Conclusions}

The presence of phenols, flavonols, and flavonoids in $V$. karroo leaves provide some scientific evidence for the conventional usage of this plant by local farmers and researchers in controlling worm load and other animal welfare challenges, such as improving nutritionally related blood metabolites, growth rate, and meat quality in livestock. The aqueous and acetone extracts of the plant showed significant potential (at $0.2 \mathrm{mg} / \mathrm{mL}$ ) as an antioxidant agent in vitro; however, further research should be carried out in order to ascertain the active compounds present in $V$. karroo leaves.

Acknowledgments: The authors are grateful to the Govan Mbeki Research Development Centre (GMRDC), University of Fort Hare, and the Department of Science and Technology/National Research Foundation (T359) for financial assistance. In addition, the authors also wish to specially thank Sagbo Jonas for technical assistance.

Author Contributions: Emrobowansan M. Idamokoro, Patrick J. Masika, and Voster Muchenje conceptualized and design the work; Emrobowansan M. Idamokoro performed the experiment; Emrobowansan M. Idamokoro collected and analyzed the data; Emrobowansan M. Idamokoro, Patrick J. Masika, and Voster Muchenje visualized the results; Emrobowansan M. Idamokoro wrote the paper; Patrick J. Masika and Voster Muchenje proofread the paper.

Conflicts of Interest: The authors declare no conflict of interest. 


\section{References}

1. Rahman, K. Studies on free radicals, antioxidants, and co-factors. Clin. Interv. Aging 2007, 2, $219-236$. [PubMed]

2. Kataria, A.K.; Kataria, N. Evaluation of Oxidative Stress in Sheep Affected with Peste des petits ruminants. J. Stress Physiol. Biochem. 2012, 8, 72-77.

3. Lykkesfeldt, J.; Svendsen, O. Oxidants and antioxidants in disease: Oxidative stress in farm animals. Vet. J. 2007, 173, 502-511. [CrossRef] [PubMed]

4. Gandhimathi, G.; Bai, G.V.S. In Vitro Antioxidant Activity of Randia dumetorum Lam leaf extract. Int. J. Herb Med. 2013, 1, 107-111.

5. Madhavi, D.L.; Salunke, D.K. Toxicological aspects of food antioxidants. In Food Antioxidants; Madhavi, D.L., Deshpande, S.S., Salunhke, D.K., Eds.; Dekker: New York, NY, USA, 1995; p. 267.

6. Adedapo, A.A.; Jimoh, F.O.; Afolayan, A.J.; Masika, P.J. Antioxidant Properties of the Methanol Extracts of the Leaves and Stems of Celtis africana. Rec. Nat. Prod. 2009, 3, 23-31.

7. Sen, S.; Chakraborty, R.; Sridhar, C.; Reddy, Y.S.R.; De, B. Free radicals, antioxidants, diseases and phytomedicines: Current status and future prospect. Int. J. Pharm. Sci. Rev. Res. 2010, 3, 91-100.

8. Mathew, S.; Abraham, E.T. In vitro antioxidant activity and scavenging effects of Cinnamomum verum leaf extract assayed by different methodologies. Food Chem. Toxicol. 2006, 44, 198-206. [CrossRef] [PubMed]

9. Nyamukanza, C.C.; Scogings, P.F. Sprout selection and performance of goats fed Acacia karroo coppices in the False Thornveld of Eastern Cape, South Africa. S. Afr. J. Anim. Sci. 2008, 38, 83-90.

10. Ngwa, A.T.; Nsahlai, I.V.; Bonsi, M.L.K. The rumen digestion of dry matter, nitrogen and cell wall constituents of pods of Leucaena leucocephala and some Acacia species. J. Sci. Food Agric. 2002, 82, 98-106. [CrossRef]

11. Xhomfulana, V.; Mapiye, C.; Chimonyo, M.; Marufu, M.C. Supplements containing Acacia karroo foliage reduced nematode burdens in Nguni and crossbred cattle. Anim. Prod. Sci. 2009, 49, 646-653. [CrossRef]

12. Marume, U.; Hugo, A.; Chimonyo, M.; Muchenje, V.; Dzama, K. Effect of dietary supplementation with Acacia karroo leaves on fatty acid profiles and consumer sensory attributes of Xhosa lop-eared goats under artificial haemonchosis. Anim. Prod. Sci. 2012, 52, 1099-1106. [CrossRef]

13. Ngambu, S.; Muchenje, V.; Marume, U. Effect of Acacia karroo supplementation on Growth, Ultimate Ph, Colour and Cooking Losses of Meat from indigenous Xhosa Lop-eared Goats. Asian Australas. J. Anim. Sci. 2013, 26, 128-133.

14. Mapiye, C.; Chimonyo, M.; Dzama, K.; Strydom, P.E.; Marufu, M.C.; Muchenje, V. Nutritional status, growth performance and carcass characteristics of Nguni steers supplemented with Acacia karroo leaf-meal. Livest. Sci. 2009, 126, 206-214. [CrossRef]

15. Otang, W.M.; Grierson, D.S.; Ndip, R.N. Phytochemical studies and antioxidant activity of two South African medicinal plants traditionally used for the management of opportunistic fungal infections in HIV/AIDS patients. BMC Complement. Altern. Med. 2012, 12, 43-50. [CrossRef] [PubMed]

16. Otunola, G.A.; Afolayan, A.J. Evaluation of the polyphenolic contents and some antioxidant properties of aqueous extracts of Garlic, Ginger, Cayenne Pepper and their mixture. J. Appl. Bot. Food Quality 2013, 86, 66-70.

17. Olajuyigbe, O.O.; Afolayan, A.J. Phenolic content and antioxidant property of the bark extracts of Ziziphus mucronata Willd subsp. Mucronata Willd. BMC Complement. Altern. Med. 2011, 11, 130-138. [CrossRef] [PubMed]

18. Liyana-Pathiana, C.M.; Shahidi, F. Antioxidant activity of commercial soft and hard wheat (Triticum aestivium L.) as affected by gastric $\mathrm{pH}$ conditions. J. Agric. Food Chem. 2005, 53, 2433-2440. [CrossRef] [PubMed]

19. Aiyegoro, A.O.; Okoh, A.I. Prelimary phytochemical screening and in vitro antioxidant activities of the aqueous extract of Helichrysum longifolium. BMC Complement. Altern. Med. 2010, 10, 2-8. [CrossRef] [PubMed]

20. Odeyemi, S.O.; Bradley, G.; Afolayan, A.J. In vitro and in vivo antioxidant activities of aqueous extract of Strychonos henningsii Gilg. Afr. J. Pharm. Pharmacol. 2010, 4, 70-78.

21. Statistical Analysis System Institute (SAS). SAS User's Guide: Statistics (Version 9.1.3); SAS Institute Inc.: Cary, NC, USA, 2007. 
22. Zheng, W.; Wang, S.Y. Antioxidant activity and phenolic compounds in selected herbs. J. Agric. Food Chem. 2001, 49, 5165-5170. [CrossRef] [PubMed]

23. Omoruyi, B.E.; Bradley, G.; Afolayan, A.J. Antioxidant and phytochemical properties of Carpobrotus edulis (L.) bolus leaf used for the management of common infections in HIV/AIDS patients in Eastern Cape Province. BMC Complement. Altern Med. 2012, 12, 215-224. [CrossRef] [PubMed]

24. Loots, D.T.; Van Der Weststhuizen, F.H.; Botes, L. Aloe ferox leaf gel phytochemical content, antioxidant capacity, and possible health benefits. J. Agric. Food Chem. 2007, 55, 6891-6896. [CrossRef] [PubMed]

25. Krishna-Kumar, H.N.; Navyashree, S.N.; Rakshitha, H.R.; Chauhan, J.B. Studies on the free radical scavenging activity of Syagrus romanzoffiana. Int. J. Pharm. Biomed. Res. 2012, 3, 81-84.

26. Wintola, O.A.; Afolayan, A.J. Phytochemical constituents and antioxidant activities of the whole leaf extract of Aloe ferox Mill. Pharmacogn. Mag. 2011, 7, 325-333. [PubMed]

27. Mohamed, H.M.; Ons, E.T.; Yosra, S.; Rayda, G.; Moncef, N. Chemical composition and antioxidant and radical-scavenging activities of Periploca laevigata root bark extracts. J. Sci. Food Agric. 2008, 89, 897-905. [CrossRef]

28. Woll, S.; Kim, S.H.; Greten, H.J.; Efferth, T. Animal plant warfare and secondary metabolite evolution. Nat. Prod. Bioprospect. 2013, 3, 1-7. [CrossRef]

29. Idamokoro, E.M.; Masika, P.J.; Muchenje, V. Prevailing management practices and perceived causes of mortality in pregnant does under free ranging farming systems in Central Eastern Cape Province of South Africa. J. Anim. Plant Sci. 2016, 27, 4272-4281.

30. Masika, P.J.; Mafu, J.V. Aspects of goat farming in the communal farming systems of the central Eastern Cape, South Africa. Small Rumin. Res. 2004, 52, 161-164. [CrossRef]

(C) 2017 by the authors; licensee MDPI, Basel, Switzerland. This article is an open access article distributed under the terms and conditions of the Creative Commons Attribution (CC BY) license (http:/ / creativecommons.org/licenses/by/4.0/). 